We hope to publish reviews of some of the papers in the abstract section of the Brit. Jl. of Ophthal.

Dr. D. N. Maitra, the Chairman of the Reception Committee in the course of his Welcome Address spoke of the importance of guarding against looking through the tube of specialism. He quoted Sir John Parsons who in his Presidential Address to the Ophthalmological Society of the United Kingdom some years ago stated that "the bane of specialism is isolation and its cure co-operation."

Dr. Maitra said that the medical practitioner besides his professional attainments should be an earnest social worker, education reformer, and seeker of economic welfare.

Sir Hassan Suhrawardy in his Opening Address welcomed those present and spoke of the vast field for ophthalmological work that there was in India and of the need for well equipped modern ophthalmic hospitals and of the necessity for prophylactic measures against blindness. He expressed the hope that postgraduate studies and a diploma in ophthalmology might be established and that the same standard of efficiency and experience would be attained as in the British Isles and on the continent.

The Presidential Address delivered by Lt.-Col. J. N. Duggan, C.I.E., O.B.E. contains a lucid and admirable account of the recent advances in ophthalmology, in particular the biochemical problems concerned in the aetiology of glaucoma and cataract; in the field of therapeutics the successes that have been attained with tuberculin and radium in certain ophthalmic disorders and the modern surgical treatment of retinal detachment. This excellent address ends with a plea for work in the prevention of eye diseases and for research carried out in a spirit of healthy co-operation.

\title{
OBITUARY
}

\section{DR. VICTOR MORAX}

Dr. Victor Morax died on May 14 in Paris. The world of ophthalmology has lost one of its most scientific exponents, the Ophthalmological Society of the United Kingdom has lost one of its three honorary members of foreign nationality, and some of us mourn a very dear friend.

Morax was born in a charming villa at Morges, on the banks of the Lake of Geneva, where his two brothers were still living in 1930, when Mayou and the writer enjoyed their hospitality one delightful evening in July, in company with Bailliart and Petit.

His medical education Morax carried out entirelv in Paris, where as a citizen of France he lived for the rest of his life. 


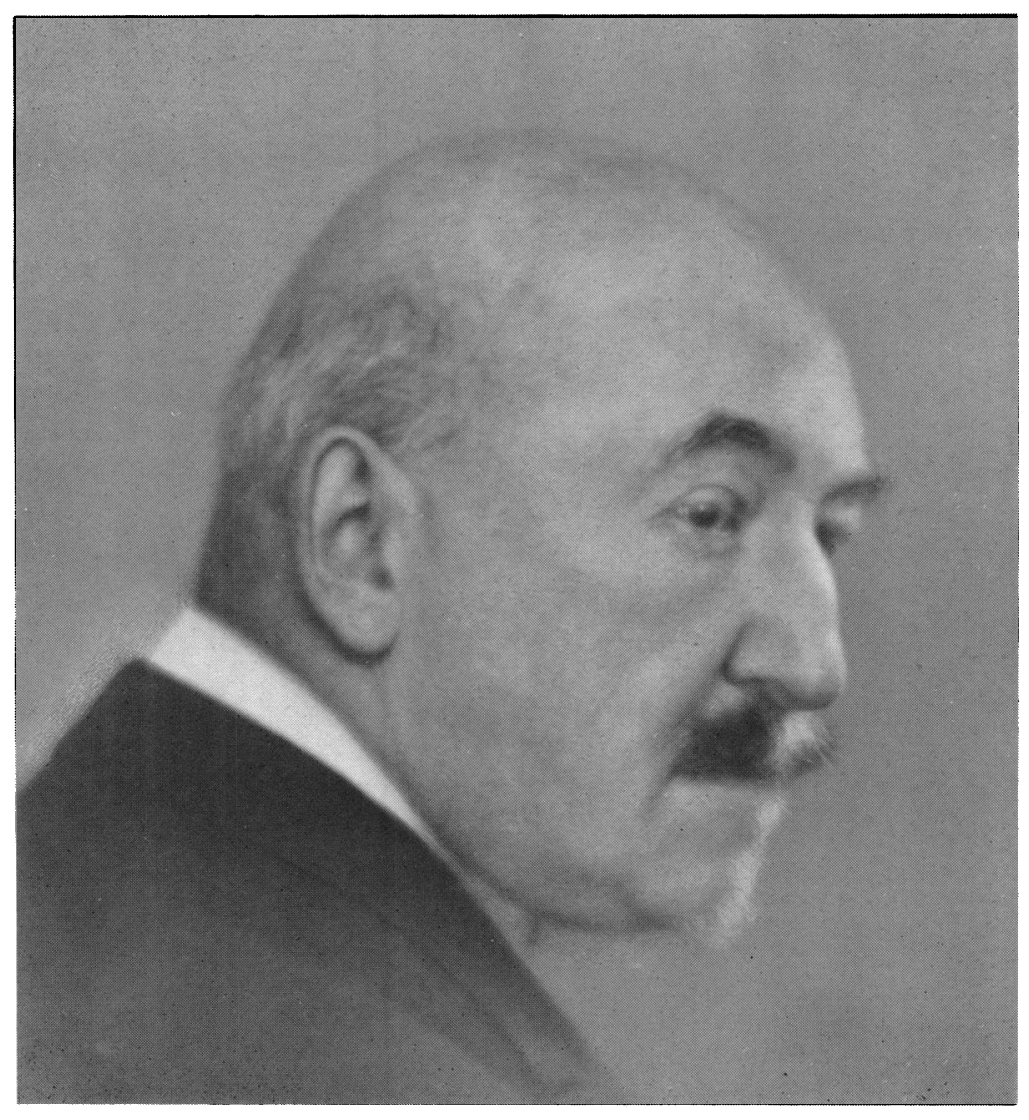

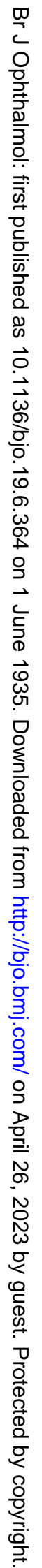


He became an expert bacteriologist, with a special interest in the flora of the conjunctiva. In 1901, as the result of an official visit to Egypt, he brought an important contribution to the study of trachoma. He determined the clinical characteristics of the disease, and showed that its acute manifestations were due to superimposed infections with the gonococcus, the Koch-Weeks bacillus and the pneumococcus. This was a highly important observation, since until then trachoma had been divided into acute and chronic categories. However it must now be recognized that rarely trachoma does begin acutely in the absence of known bacterial invasion.

In 1906 he described a diplobacillus in Annales de l'Institut Pasteur, the pathogenic qualities of which were confirmed by the researches of Axenfeld in the same year, and the organism is commonly known as the diplobacillus of Morax-Axenfeld.

In 1919 he delivered the Bowman Lecture before the Ophthalmological Society of the United Kingdom, his subject being "Plastic Operations in the Orbital Region." This had special reference to war wounds. A study of this paper is essential for all ophthalmic surgeons who may have to deal with wounds involving the orbit.

From 1903 to 1929 Morax directed the clinical work at the Lariboisiére Hospital in Paris, where he had facilities for continuing his important bacteriologicail studies. Since then he was granted a room for research at the Pasteur Institute, where he spent much time.

Realizing the importance of trachoma as a world-wide disease he was the main-spring of La Ligue Contre le Trachome. This French society commenced in 1924 the publication of a journal $\mathrm{La}$ Revue du Trachome. As the only journal which dealt entirely with trachoma it obtained world-wide influence. In 1926 the growing importance of the trimestrial publication justified the alteration of its title to La Revue Internationale $d u$ Trachome. It accepts articles in any European language, and gives summaries of all important articles on trachoma which are published in the medical journals of other countries.

Morax brought out the fourth edition of his Précis d'Ophtalmologie in 1931. In the opinion of some who are qualified to judge it is the best text-book on ophthalmology in any language.

During each of the last ten years the Bulletin de la Société française d'Ophtalmologie has always contained an important paper by Morax. Perhaps the most interesting of his contributions has been his report on the different varieties of follicular conjunctivitis in the 1933 volume.

For the International Congress of Ophthalmology at Madrid in 1933 he prepared an important report on the microbiological aetiology of trachoma. 
Morax was a member of the Executive Committee of the International Organization of the Compaign against Trachoma and played an important part in its work.

He was elected a member of the Academie de Medicine in 1930. He married the daughter of the late Professor Pinard, by whom he had six sons.

\section{NOTES}

Erratum for "neuro-" read "retro-."

IN Mr. Marshall's paper in the April issue: p. 197, end of 14th line from bottom of page,

North of England

Ophthalmological

Society. Officers of

AT the Annual Meeting of the Society on April 12 the following members were elected to the Council for the Session, October, 1935, to October, 1936 :-President: Mr. A. T. Paterson, Newcastle-onTyne; Vice-President: Mr. W. W. Muirhead, Sheffield; Members of Council: Mr. O. M. Duthie, Manchester ; Mr. P. Eldon Gorst, Liverpool. The Treasurer and Secretary were re-elected.

The Leslie Dana Gold Medal
The Leslie Dana Gold Medal, awarded annually for outstanding achievements in the Prevention of Blindness and the conservation of vision, has been awarded to Dr. William H. Wilder, of Chicago.

Last year's recipient was Professor de Lapersonne, of Paris.

\section{FUTURE ARRANGEMENTS}

\section{5}

June 14.-Section of Ophthalmology, Royal Society of Medicine (Annual Meeting).

July 4, 5 and 6.-Oxford Ophthalmological Congress, at Oxford.

July 29-August 2.-Second International Neurological Congress, in London.

October 1.-Midland Ophthalmological Society, at Birmingham Eye Hospital.

December 3.-Midland Ophthalmological Society, at Birmingham Eye Hospital. 